Check for updates

Montreal, Canada

Cite this as: $B M J$ 2021;373:n1053 http://dx.doi.org/10.1136/bmi.n1053 Published: 21 April 2021

\section{Covid-19: Canada relaxes age limits on AstraZeneca vaccine as Ontario cases surge}

\author{
Owen Dyer
}

Three weeks after restricting the AstraZeneca vaccine to people aged 55 and older, provinces across Canada have reversed course and expanded access to include anyone aged over 40, faced by surging case numbers in Alberta and the country's most populous province, Ontario.

Canada's National Advisory Committee on Immunisation (NACI) was expected to recommend the reversal on 20 April based partly on a review of recent US blood clotting events. ${ }^{1}$ But NACI cancelled its press conference five minutes before it was to start, citing the need to "further validate its data analysis." Most provinces, however, had already adopted the expected change earlier that day. Lines formed outside pharmacies across Canada as people in their 40 and early 50 became eligible for vaccination for the first time.

The policy change was driven by surging case numbers in Ontario and Alberta, where the B.1.1.7 or UK variant dominates.

“Our situation is dire,” Ontario’s deputy chief medical officer Barbara Yaffe told reporters this week. "Trends in key health indicators have deteriorated to levels far exceeding anything we've seen before.” About $70 \%$ of patients have the variant, and their risk of intensive care unit (ICU) admission is doubled, said chief medical officer David Williams. "We're having more and more people in the 40 to 60 age group coming in quite ill and filling up our ICU."

Barb King, an emergency physician in Markham, Ontario, released triage rules for a major surge which staff have been told will be in force within days. ${ }^{2}$ "Unless you have a 70\% chance of surviving your intubation or resuscitation and ICU care you will be allowed to die," she wrote on Twitter. ${ }^{3}$

Canada has lost 624 people per million population to covid-19, about one third of the toll in the UK or US. Even as Canada lags behind the US in vaccinations, its death toll remains lower. Canada recorded 8.5 deaths per million population from covid-19 over the past seven days. The figure was 12 in Ontario and 15.7 in the US.

But the surge in Alberta and Ontario has Canada on track to surpass the US daily per capita death rate for the first time. The seven day average of new daily cases per 100 ooo is 20.3 in the US, 22.7 in Canada, and 29.6 in Ontario. The test positivity rate in both Alberta and Ontario is $10.4 \%$.

\section{"Upside down" response under fire}

Ontario's Conservative premier, Doug Ford, has faced numerous calls for his resignation ${ }^{4}$ for shutting down later and reopening earlier than experts advised. Most outdoor activities remain banned, but calls to improve indoor worker protection and close risky industries went unheeded, critics say. "He's got the science absolutely upside down," University of Toronto epidemiologist David Fisman told Global News.

Rajiv Singal, chief surgeon at Toronto’s Michael Garron Hospital, tweeted, "We are about to go through what Italy and New York went through a year ago. I can't believe we are at this place in Ontario today. Neither of those places had warning. We had one full year to prevent this."

In one of several forced policy retreats, a closure of Ontario's playgrounds announced last week was swiftly reversed following public outcry. On 20 April, amid mounting pressure, a spokesman for Ford said that the provincial government will consider supporting paid sick leave, an idea it has resisted for months.

Ford has blamed the federal government for slow delivery of vaccines. Canada has provided at least one vaccine dose to $27.6 \%$ of its total population, compared with $40.1 \%$ in the US. But while neighbouring Quebec and Manitoba share Ontario's vaccination rate, they have far fewer cases. Their borders with Ontario were sealed on 19 April.

Canada's prime minister Justin Trudeau, announcing emergency medical aid for the province, showed no inclination to come to the rescue of its embattled premier. "We are mobilising federal healthcare workers from across government departments to deploy to the frontlines in Ontario," said Trudeau. "There are provinces that have managed their healthcare capacity for their own local situation and have the ability to lend a hand to others."

Trudeau, 49, said on 20 April that, having just become eligible, he will seek a vaccination in the next few days. A Ford spokesman announced that evening that the premier was self-isolating after a close staffer tested positive. Ford, 56, received the AstraZeneca vaccine three weeks ago.

\footnotetext{
Taquet M, Husain M, Geddes JR, Luciano S, Harrison PJ. Cerebral venous thrombosis: a retrospective cohort study of 513284 confirmed covid-19 cases and a comparison with 489871 people receiving a covid-19 mRNA vaccine. https://osf.io/a9jdq/download

2 Ontario Critical Care Covid Command Centre. Adult critical care clinical emergency standard of care for major surge. January 2021. www.aodaalliance.org/wp-content/uploads/2021/01/Ontario-Adult-Critical-CareEMERGENCY-STANDARD-OF-CARE-OCCCCC-20210113.pdf.

3 King B. 19 April 2021. https://twitter.com/DrBarbKing/status/1384136625362333704.

4 Moscrop D. Doug Ford must resign. Washington Post. 18 April 2021 www.washingtonpost.com/opinions/2021/04/18/ontario-covid-lockdowndoug-ford-canada.
}

This article is made freely available for use in accordance with BMJ's website terms and conditions for the duration of the covid-19 pandemic or until otherwise determined by BMJ. You may use, download and print the article for any lawful, 
non-commercial purpose (including text and data mining) provided that all copyright notices and trade marks are retained. 